\title{
Wilms Tumor 1 Protein is not Expressed in Oral Lymphangiomas
}

\author{
Ana Carolina de Mesquita NETTO ${ }^{1}$ \\ Mariana Batista de OLIVEIRA ${ }^{1}$ \\ Vanessa Fátima BERNARDES ${ }^{1}$ \\ Carolina Cavaliéri GOMES ${ }^{2}$ \\ Ricardo Santiago GOMEZ ${ }^{1}$ \\ ${ }^{1}$ Department of Oral Surgery and Pathology, Dental School, \\ UFMG - Universidade Federal de Minas Gerais, Belo Horizonte, MG, Brazil \\ ${ }^{2}$ Department of Pathology, Biological Sciences Institute, \\ UFMG - Universidade Federal de Minas Gerais, Belo Horizonte, MG, Brazil
}

\begin{abstract}
Lymphangiomas are benign hamartomatous lesions of lymphatic vessels. Wilms Tumor 1 (WT1) is a transcription factor that is activated in some human neoplasias. WT1 protein expression is observed in endothelial cells during angiogenesis and is a useful marker to distinguish between vascular proliferations and vascular malformations. The purpose of the present study is to report a case series of oral lymphangiomas together with an immunohistochemical investigation of WT1. Seventeen cases of oral lymphangioma were retrieved and reviewed. Immunohistochemical analysis of WT1 protein was performed and pyogenic granuloma samples were used as positive controls. The male/female ratio was 1.125 and most of the lesions occurred in young subjects. While pyogenic granuloma showed positive staining for WT1, the endothelial cells lining the thin-walled dilated lymphatic vessels of lymphangiomas were negative for this protein. The findings strengthen the idea that oral lymphangioma is a vascular malformation characterized by lymphatic dilatation without significant endothelial proliferation.
\end{abstract}

Key Words: oral lymphangioma, WT1, Wilms tumor 1.

\section{INTRODUCTION}

Lymphangiomas are benign hamartomatous lesions of lymphatic vessels that show a marked predilection for the head, neck and oral cavity (1). Histopathologically, they consist of dilated cystic spaces containing proteinaceous eosinophilic fluid, lined by fine septa containing flattened endothelial cells (2). Mucosal and cutaneous involvement results in the formation of multiple fluid vesicles, which may communicate with larger and deeper lymphatic cisterns (3). This lesion manifests at birth or during the first years of life (4). Three types of lymphangiomas in the head and neck region may be distinguished: lymphangioma simplex, which is composed of thin-walled capillary-sized lymphatic channels; cavernous lymphangioma, composed of large, dilated lymphatic vessels; and cystic hygroma, which shows large, macroscopic cystic spaces (5). The retained lymph in the lymphatic vessels produces a soft, compressible swelling in the oral mucosa. Lymphangiomas are also classified radiographically in one of two types: lymphangiomas with cysts larger than $2 \mathrm{~cm}$ in diameter are "macrocystic," and those with cysts smaller than this are "microcystic". Several research groups have noticed a difference in clinical behavior between microcystic and macrocystic lesions (6).

Wilms Tumor 1 (WT1) is a transcription factor that is activated in some human neoplasias, including Wilms Tumor $(7,8)$. WT1 may be linked to the uncontrolled epithelial-to-mesenchymal transition observed in a number of developmental abnormalities and diseases (9). It is interesting that although WT1 is inactive in some Wilms tumors, similar to a tumor suppressor gene, it does not always conform to the label

Correspondence: Ana Carolina de Mesquita Netto, Departamento de Clínica, Patologia e Cirurgia Odontológicas, Faculdade de Odontologia, Universidade Federal de Minas Gerais, Avenida Antônio Carlos, 6627, 31270901 Belo Horizonte, MG, Brasil. Tel: +55-31-3409-2477. Fax: +5531-3409-2430. email: netto_carol@yahoo.com 
of a tumor suppressor gene since it may also enhance cell survival and proliferation, like an oncogene (10).

WT1 protein expression was studied in skin biopsy samples of endothelial proliferations and tumors (11). The authors observed that WT1 expression is maintained during angiogenesis and malignant transformation of endothelial cells (12). Furthermore, the transcription factor encoded by WT1 gene is expressed in the endothelium of hemangiomas but not in vascular malformations (13). Immunohistochemical detection of WT1 could be useful to investigate vascular anomalies allowing the distinction of vascular proliferations from vascular malformations (12).

The purpose of the present study was to report a case series of oral lymphangiomas together with an immunohistochemical investigation of WT1. The hypothesis tested is that since oral lymphangiomas are vascular malformations they are not expected to express this protein.

\section{MATERIAL AND METHODS}

The files of the UFMG's Oral Pathology Laboratory Service, Brazil, were reviewed from 1961 to 2012. Seventeen cases of oral lymphangioma were retrieved from the files and the diagnoses were reviewed. Thirteen samples containing paraffin embedded tissue blocks with sufficient tissue for immunohistochemical analysis were selected. Sections of the tumors were evaluated by HE staining and the immunohistochemical (IHC) reactions for detection of the WT1 protein were performed using mouse monoclonal antibody (Clone 6F-H2; Dako, Carpinteria, CA, USA). The processes of deparaffinization, hydration and antigen retrieval were performed by immersing the slides in Trilogy solution (Cell Marque, Rocklin, CA, USA), and heating to $98^{\circ} \mathrm{C}$ in a steamer for $20 \mathrm{~min}$. The primary antibody was diluted at 1:100 and incubated for $30 \mathrm{~min}$ at room temperature. EnVision ${ }^{\mathrm{TM}}+$ Dual Link System-HRP (Dako) was used as the detection system for $30 \mathrm{~min}$ at room temperature. The reactions were revealed by applying 3,3'-diaminobenzidine as chromogen solution (DAB) (Dako) and Mayer's hematoxylin was used for counterstaining. The slides were mounted in Permount (Fisher Scientific, Bridgewater, NJ, USA). IHC was performed manually and three pyogenic granuloma samples were used as positive control. Negative controls were carried out with omission of the primary antibody, resulting in no detectable staining. The isotype-matched mouse monoclonal antibody with irrelevant specificity ( $\mathrm{IgG}_{1}$ kappa) was used to establish the background and the zero point of analysis.

\section{RESULTS}

The main clinical characteristics of all oral lymphangioma cases are in Table 1. The lesions affected mainly young subjects, the male/female ratio was 1.125 and the main location was the tongue. All lesions presented histological features characteristic of oral cavernous lymphangioma (Figs. 1A and 1B).

Pyogenic granuloma was used as control, for it presents proliferating endothelial cells and shows positive staining for WT1 (12). No staining for WT1 was observed in flattened endothelial cells lining the thin walls of the dilated lymphatic vessels of the lymphangioma cases (Fig. 1C). On the other hand, all pyogenic granulomas showed positive labeling for WT1 in the cytoplasm of the proliferating endothelial cells and in some inflammatory cells (Fig. 1D).

\section{DISCUSSION}

It has been postulated that lymphangioma

Table 1. Clinical data of lymphangioma cases included in the study.

\begin{tabular}{lc}
\hline Category & Result \\
\hline Age & 18 years \\
Mean & 15 years \\
Median & $6-41$ years \\
Range & \\
Gender & 9 patients \\
Male & 8 patients \\
Female & \\
Location & 7 lesions \\
Tongue & 5 lesions \\
Buccal mucosa & 1 lesion \\
Lip & 2 lesions \\
Soft palate & 1 lesion \\
Floor of mouth & 1 lesion \\
Vestibule & 17 lesions \\
Total (n) & \\
\hline
\end{tabular}


develops as a result of sequestration of primitive embryonic lymphatic anlage that do not achieve efficient anastomoses with lymph channels (1). In our case series, the dorsal surface of the tongue was the most affected site and the lesions occurred mainly in young patients. In general, the obtained clinical data agree with those reported in the literature (1). The cavernous type was found in all cases in the present study, which confirms that most tongue lymphangiomas belong to the cavernous type (14).

In the present study, none of the oral lymphangioma cases expressed WT1. Although a previous case of lymphangiomatosis-like growth affecting the uterine tissues showed similar findings (15), to the best of our knowledge this protein was not previously investigated in oral lymphangiomas. As negative labelling for WT1 is expected in sanguineous vascular malformation, but not in true neoplastic hemangiomas, the present findings are in accordance with the malformation of non-proliferative nature of oral lymphangiomas. The collected data also confirm previous evidence that cavernous lymphangioma may be attributed to the enlargement of lymphatic vessels without the tumorous proliferation of lymphatic endothelial cells (14).

In conclusion, these findings, together with the current data available in the literature strengthen the idea that oral lymphangioma is a vascular malformation characterized by lymphatic dilatation without significant endothelial proliferation.

\section{RESUMO}

Os linfangiomas são tumores hamartomatosos benignos dos vasos linfáticos. O Wilms Tumor 1 (WT1) é um fator de transcrição que se encontra ativo em algumas neoplasias humanas. A expressão da proteína WT1 é observada em células endoteliais durante a angiogênese e pode ser um marcador útil para distinguir as proliferações vasculares das malformações vasculares. O objetivo deste estudo foi relatar uma série de casos de linfangiomas orais e avaliar a expressão imunoistoquímica da proteína WT1. Dezessete casos de linfangiomas orais foram recuperados e revisados. A análise imunoistoquímica foi realizada e amostras de granuloma piogênico foram utilizadas como controle positivo. A relação homem/mulher foi de 1,125 e a maioria das lesões acometeram pacientes jovens. Enquanto o granuloma piogênico mostrou uma imunopositividade para WT1, as células endoteliais da fina parede dos vasos linfáticos dilatados apresentaram-se negativas para esta proteína. Tais achados reforçam a idéia de que o linfangioma oral é uma malformação vascular caracterizada por dilatação linfática sem uma proliferação endotelial significativa.
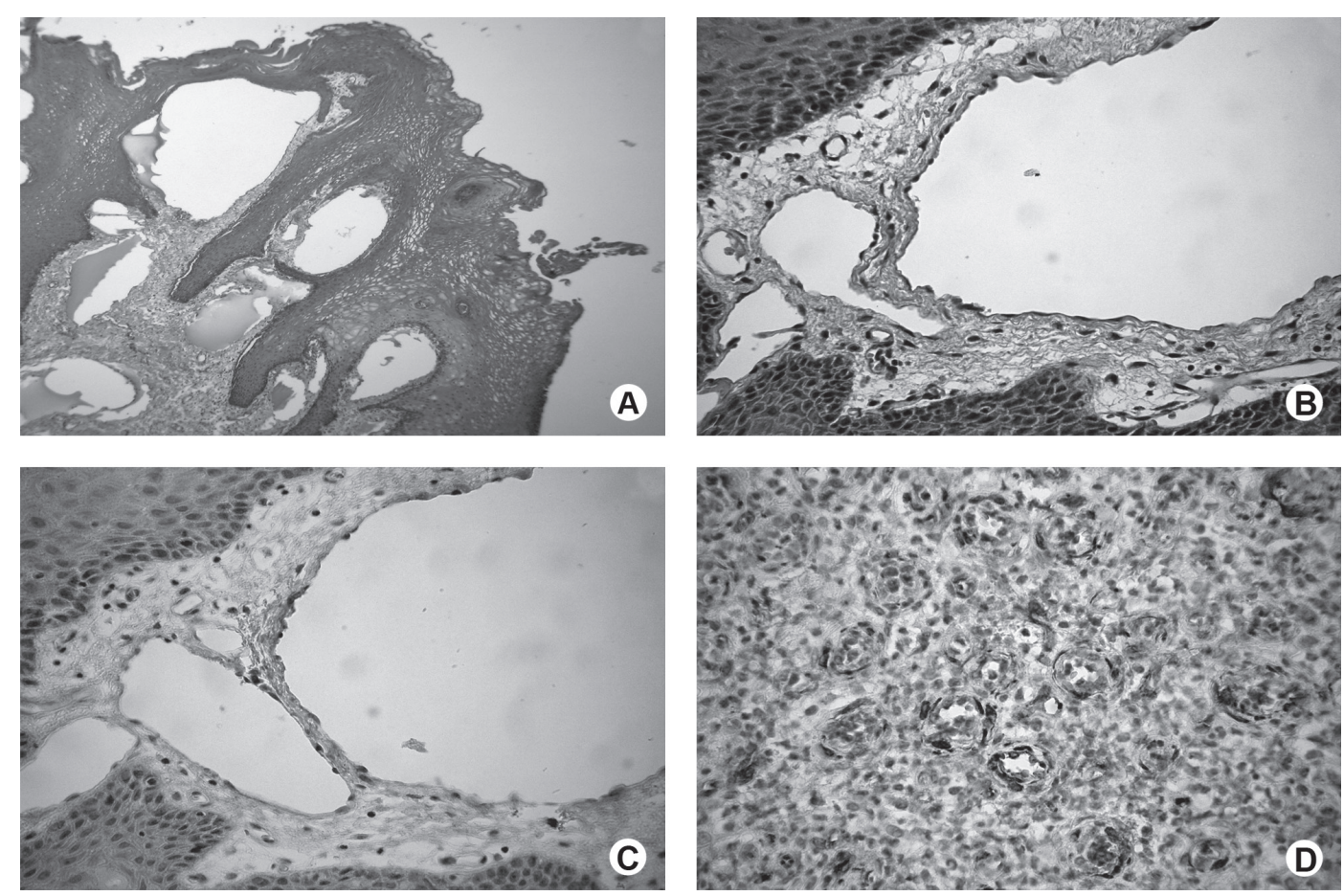

Figure 1. Histopathological features and WT-1 immunoexpression. A: Dilated lymphatic channels partially filled with proteinaceous fluid $(\mathrm{HE} \times 100)$. B: Lymphatic vessels exhibiting flattened endothelial cells $(\mathrm{HE} \times 400)$. C: Negative expression of WT-1 in endothelial cells of lymphatic vessels $(\times 400)$. D: Pyogenic granuloma used as positive control demonstrating WT-1 expression in proliferating endothelial cells $(\times 400)$. 


\section{REFERENCES}

1. Brennan TD, Miller AS, Chen SY. Lymphangiomas of the oral cavity: a clinicopathologic, immunohistochemical, and electronmicroscopic study. J Oral Maxillofac Surg 1997;55:932-935.

2. Gray G, Fried K, Iraci J. Cystic lymphangioma of the pancreas: CT and pathologic findings. Abdom Imaging 1998;23:78-80.

3. Whimster IW. The pathology of lymphangioma circumscriptum. Br J Dermatol 1976;94:473-486.

4. Van der Wall I. Lymphangioma. In: Pathology \& Genetics Head and Neck Tumours. Barnes L, Eveson JW, Reichart P, Sidransky D (Editors). Lyon: IARC Press;2005.p195.

5. Neville BW, Damm DD, Allen CM, Bouquot JE. Soft tissue tumours. In: Oral and Maxillofacial Pathology. $3^{\text {rd }}$ ed. St Louis: Saunders Elsevier; 2009 p.547-549.

6. Chen EY, Hostikka SL, Oliaei S, Duke W, Schwartz SM, Perkins JA. Similar histologic features and immunohistochemical staining in microcystic and macrocystic lymphatic malformations. Lymphat Res Biol 2009;7:75-80.

7. Oue T, Uehara S, Yamanaka H, Takama Y, Oji Y, Fukuzawa M. Expression of Wilms tumor 1 gene in a variety of pediatric tumors. J Pediatr Surg 2011;46:2233-2238.

8. Owen C, Fitzgibbon J, Paschka P. The clinical relevance of Wilms tumour 1 (WT1) gene mutations in acute leukaemia. Hematol Oncol 2010;28:13-19.
9. Miller-Hodges E, Hohenstein P. WT1 in disease: shifting the epithelial-mesenchymal balance. J Pathol 2012;226:229-240.

10. Huff V. Wilms' tumours: about tumour suppressor genes, an oncogene and a chameleon gene. Nat Rev Cancer 2011;11:111121.

11. Timar J, Meszaros L, Orosz Z, Albini A, Raso E. WT1 expression in angiogenic tumours of the skin. Histopathology 2005;47:67-73.

12. Al Dhaybi R, Powell J, McCuaig C, Kokta V. Differentiation of vascular tumors from vascular malformations by expression of Wilms tumor 1 gene: evaluation of 126 cases. J Am Acad Dermatol 2010;63:1052-1057.

13. Lawley LP, Cerimele F, Weiss SW, North P, Cohen C, Kozakewich HP, et al.. Expression of Wilms tumor 1 gene distinguishes vascular malformations from proliferative endothelial lesions. Arch Dermatol 2005;141:1297-1300.

14. Yaita T, Onodera K, Xu H, Ooya K. Histomorphometrical study in cavernous lymphangioma of the tongue. Oral Dis 2007;13:99-104.

15. Patel RC, Zynger DL, Laskin WB. Blue rubber bleb nevus syndrome: novel lymphangiomatosis-like growth pattern within the uterus and immunohistochemical analysis. Hum Pathol 2009;40:413-417.

Received August 16, 2012 Accepted December 5, 2012 